\title{
Domestic Violence and Covid-19: Strategies for Helping Victims
}

\author{
Daleleer Kaur Randawar, Sheela Jayabalan, Nur Ezan Rahmat \& Najibah \\ Binti Mohd Zin
}

To Link this Article: http://dx.doi.org/10.6007/IJARBSS/v11-i11/11053

DOI:10.6007/IJARBSS/v11-i11/11053

Received: 07 September 2021, Revised: 10 October 2021, Accepted: 26 October 2021

Published Online: 09 November 2021

In-Text Citation: (Randawar et al., 2021)

To Cite this Article: Randawar, D. K., Jayabalan, S., Rahmat, N. E., \& Zin, N. B. M. (2021). Domestic Violence and Covid-19: Strategies for Helping Victims. International Journal of Academic Research in Business and Social Sciences, 11(11), $1307-1316$.

\section{Copyright: @ 2021 The Author(s)}

Published by Human Resource Management Academic Research Society (www.hrmars.com)

This article is published under the Creative Commons Attribution (CC BY 4.0) license. Anyone may reproduce, distribute, translate and create derivative works of this article (for both commercial and non-commercial purposes), subject to full attribution to the original publication and authors. The full terms of this license may be seen

at: http://creativecommons.org/licences/by/4.0/legalcode

Vol. 11, No. 11, 2021, Pg. $1307-1316$

Full Terms \& Conditions of access and use can be found at http://hrmars.com/index.php/pages/detail/publication-ethics 


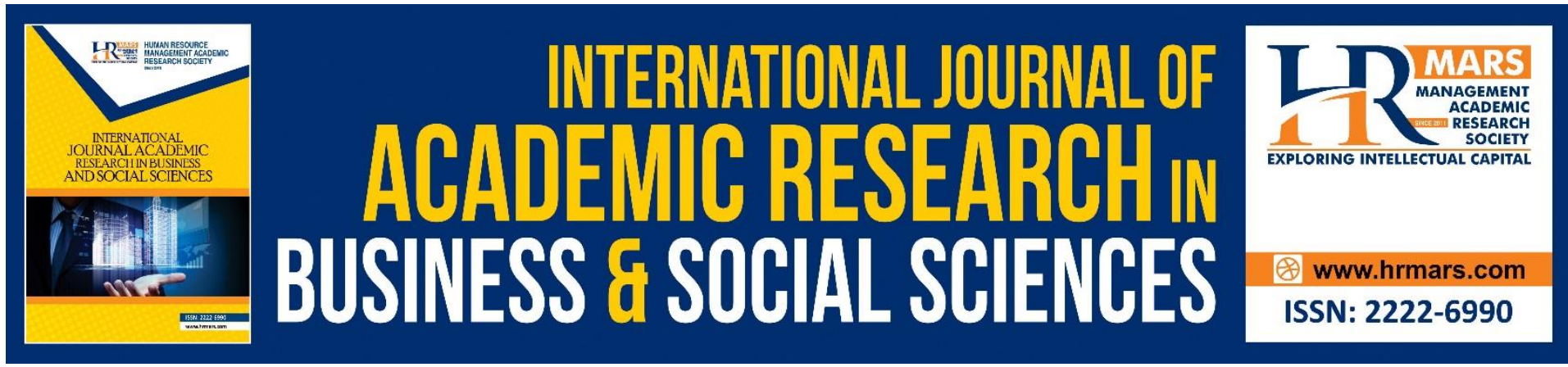

\title{
Domestic Violence and Covid-19: Strategies for Helping Victims
}

\author{
Daleleer Kaur Randawar ${ }^{1}$, Sheela Jayabalan², Nur Ezan \\ Rahmat $^{3} \&$ Najibah Binti Mohd Zin ${ }^{4}$ \\ 1,2,3 Faculty of Law, Universiti Teknologi Mara (UiTM), 40450 Shah Alam, Selangor Darul \\ Ehsan, Malaysia, ${ }^{4}$ Ahmad Ibrahim Kulliyyah of Laws, International Islamic University, 50728 \\ Kuala Lumpur, Malaysia.
}

\begin{abstract}
This paper apart from examining the strategies and ways to assist victims of domestic violence during the COVID-19 pandemic also looks into the adequacy of the current legal and social support systems in addressing the issue of domestic violence during the COVID19 pandemic in Malaysia. This study was conducted primarily through a doctrinal study of existing literature such as statutory provisions, articles, journals and reports related to the current concerns. A comparative analysis of the strategies employed by some of the countries was carried out to obtain solutions to address domestic violence in Malaysia. The findings prove that the current legal and support system is inadequate to meet the contemporary needs of victims of domestic violence during the COVID-19 pandemic. It is believed that the findings in this research will significantly improve the current legislative framework governing situations during a pandemic and benefit researchers, academicians, legal practitioners, students and scholars.
\end{abstract}

Keywords: Domestic Violence, COVID-19, Protection, Strategies, Victims.

\section{Introduction}

During the outbreak of the COVID-19 pandemic, an increase in domestic violence cases was observed through the number of cases reported worldwide. The Malaysian government has also revealed that its welfare hotline observed a 57 per cent spike in the number of calls received since the nation's Movement Restriction Order (MRO) was initiated in mid-March. It has, however, maintained that not all these calls were related to domestic violence as financial and marital problems were also aired (Sukumaran, 2020). The MyCareCov19 helpline launched by the Islamic Development Department (Jakim) received 841 calls and 136 e-mail messages which were related to marriage and divorce matters (Baharin, 2020). Apart from Jakim, the Women's Aid Organisation (WAO) had also received 234 calls and messages from women in distress and this was a four-fold increase in the number of calls and messages documented on a weekly basis prior to the enforcement of the Movement Control Order (MCO) (Baharin, 2020).

An incident during the MCO found a man dead in his home after he had inflicted harm on his wife and father-in-law. Immediately after stabbing his wife and father-in-law, the man 
hanged himself on 1 May 2020. The 40-year-old woman reported that she had been beaten repeatedly by her unemployed husband (Timbuong, 2020). According to the victim (wife), she was struck with a stick on the back and punched in the stomach and head by the suspect because of financial problems. The wife lodged a report after her husband allegedly struck her. The woman (wife), accompanied by her father and suspect, was called in for questioning by the police. When the police intervened, the suspect promised to settle their differences peaceably (Timbuong, 2020). However, upon returning home, the suspect immediately ran inside, grabbed a knife and stabbed the victim and her father. The neighbours, having heard the commotion, reported the incident to the police who rushed to the couple's home and gained entry by breaking down the door as it was locked from inside. When the police finally made their way in, the husband was found hanging from the ceiling fan in a room on the ground floor. The wife and the father-in-law, fortunately, survived the attack. (Timbuong,2020).

Prior to the COVID-19 pandemic in Malaysia, domestic violence has been highly prevalent and of great concern, and with the victims sharing the same domestic spaces with the abusers, the former is exposed to greater risk during the lockdown period. The issue of domestic violence is not novel in Malaysia. This abuse worries the victims as it instils fear of future violent attacks. The home a place of shelter and refuge may not be so for some who undergo violence in its four corners (Randawar, 2016). Moreover, domestic violence is perceived as a "personal matter" and since this offence happens within the confines of a home, it often goes unreported (Randawar, 2016).

Campbell (2020) highlighted that many countries while implementing measures to reduce the spread of the virus, indirectly encounter increase in the risk of domestic violence. Consequently, there is a dire need to address domestic violence during a pandemic and this paper examines strategies and ways to assist victims of domestic violence during the COVID19 outbreak. The article will also study the relevant legal protections available and suggest ways to further improve them to assist victim of domestic violence during the pandemic. Several methods and strategies employed in other jurisdictions to help victims of domestic violence during this crisis will also be pointed out.

\section{Challenges Faced}

Various forms of challenge are faced by society during this COVID-19 pandemic which have affected all segments of the population in the political, economy and social areas. Therefore, support is imperative to control the spread of this zoonotic disease (Wu, Chen \& Chan, 2020). According to the Malaysian Economic Research Institute (MIER), COVID-19 has caused unemployment for 2.4 million employees (Makhbul, 2020). Subsequently, many business owners and wage earners have been adversely impacted by this pandemic (Rashid, 2020, Astro Awani).

The situation during the current COVID-19 pandemic is worse for women in developing countries who experience higher gender inequality and greater participation in informal sectors. Workers in the informal sector as well as in small and medium enterprises encounter poor financial prospects during a crisis as they are unable to work from home or secure paid leave from large companies (Kapoor, 2020). Kapoor also stressed daily wage earners do not have sufficient savings to purchase necessities, ease of excess to infrastructure (i.e., online banking and e-commerce) and are ill-equipped to deal with lockdown measures. According to research conducted by Ramaswamy et al (2020), although women have tried to comply 
with the virus prevention recommendations stipulated, they were still unable to control the behaviour of others in volatile homes.

\section{Protection Under the Law}

The Malaysian government passed the Domestic Violence Act (Act 521) in 1994 (DVA 1994). With its recent amendments enforced on 1 January 2018, added and desired protection in the form of an Emergency Protection Order (EPO) were incorporated into the DVA 1994. The act provides protection and compensation to the victims of domestic violence. Despite the presence of the Act, challenges were still confronted by domestic violence victims during the MCO. Laws made should be sufficiently flexible to encompass all circumstances. The DVA 1994 provides the following protection: Emergency Protection Order (EPO), Interim Protection Order (IPO) and Protection Order (PO).

\section{Emergency Protection Order (EPO)}

Before the amendment, the DVA only provided protection in the form of IPO and PO. The amendment of the Domestic Violence Act 2017 has incorporated the EPO to offer immediate protection for victims and to avoid criminal proceedings against the perpetrator at the initial stage of an abuse (Randawar \& Najibah, 2019).

Section 3A (1) of the DVA allows an EPO to be issued by a social welfare officer within two hours after the application is completed (Section 3A (5) of the DVA 1994). Furthermore, according to Section 3A (6) of the DVA 1994, an application for an EPO is rendered complete without a police report. Under Section $3 A(7)(a)(b)(c)$ the EPO also contains orders prohibiting the abuser from inflicting violence, inciting others to cause violence and preventing him from entering the shelter/ place of residence/ shared residence or alternative residence of the protected person. This EPO is valid for a period of seven days from the date of issuance (Section 3(A) (8) of the DVA 1994).

Hence, the EPO provides immediate interim protection for victims of domestic violence without having to lodge a police report or be physically present at the court. Due to restrictions during MCO, the EPO became a critical mechanism to protect survivors of domestic violence under the DVA 1994. Since there is no stipulation to be present at the police station and court, the application for an EPO should be allowed via telephone. Indirectly, this method monitors the abuser's action and movements.

The introduction of EPO is more family-friendly where the involved parties can collaborate to preserve domestic relationships (Randawar \& Zin, 2019). It is proposed that the EPO be used as a credible mechanism to safeguard victims of domestic violence during the MCO period as it can be issued by a social welfare officer.

\section{Interim Protection Order (IPO)}

Compared to the EPO and according to Section 4(1) and Section 12 of the DVA 1994, an IPO needs to be issued by the court during the pendency of police investigations into incidents of domestic violence. As such, Section 4(2) of the DVA 1994 clearly states that the application of IPO can only be made by way of application to the court. Thus, the application of an IPO which requires a police report to be attached allows the police to commence an investigation involving domestic violence. An improved provision in the IPO in the new 2017 amendments under Section 4(3A) of the DVA 1994 states that during an IPO, victims are entitled to similar treatments or orders as stipulated under a Protection Order (PO) and which are indicated under Section 6(1)(a)-(f) of the DVA 1994. Hence, orders such as exclusive 
occupation of the shared residence; prohibiting the abuser from entering the residence, place of employment and school; permit the protected person to enter the home to collect personal belongings accompanied by an enforcement officer; requiring the abuser refrain from communicating with the victim and requiring the victim to continue use of vehicle, under the DVA have been made available to victims even during the IPO.

An IPO becomes redundant in 3 situations as seen under section 4(4) (a) (b) (c) of the DVA 1994. They include the following:

(1) When the police inform the victim in writing that the investigations have completed, and no further action will be taken against the abuser;

(2) When the police inform the victim in writing that a criminal proceeding relating to the commission of an offence involving domestic violence will be instituted against the abuser and the victim is yet to apply for a Protection Order within seven days after being informed;

(3) When the police inform the victim in writing that criminal proceedings related to the commission of an offence involving domestic violence will be instituted against the abuser and upon the determination of an application for PO by the court, the application for PO is made within seven days.

Hence, the IPO becomes operative during the entire duration of an investigation by the police. Termination of the IPO occurs immediately upon the completion of the investigations which indicates that an IPO only operates as an interim injunction to stop the act of abuse by the husband or to stop others encouraged by the abuser to commit domestic violence against the victim (Randawar \& Zin, 2019).

An IPO ends when a criminal proceeding of domestic violence offence is instituted against the offender to indicate that the investigation has been completed and the accused has been found guilty (Randawar \& Zin, 2019).

\section{Protection Order (PO)}

A PO may be granted by the court in proceedings involving a complaint of domestic violence pursuant to Section 5(1) of the DVA (Randawar \& Jayabalan, 2014). The court may grant a Protection Order to prevent the abuser from inflicting domestic violence against the victim, a child and an incapacitated adult (Randawar \& Jayabalan, 2014).

The granting of a PO according to Section 13 of the DVA 1994, is done within seven days after informing the victim that a criminal proceeding will be instituted against the perpetrator. During this trial the criminal offence, within the definition of domestic violence, must be compoundable or bailable under the Criminal Procedure Code. Similar to IPO, the PO granted under Section 5 of the DVA 1994 may include same of the orders available under Section 6(1) (a)-(f) of the DVA 1994. All these orders will only be effective for a period not exceeding twelve months [Section 6(1)(1A) of the DVA 1994] and may later be extended for a further period not exceeding twelve months from the date of the expiration of the original order [Section 6(2)(b) of the DVA 1994]. Thus, a PO from the date of its issuance can only be valid for twelve months and later be extended for another twelve months.

Under the law, an IPO and PO can only be obtained through application from the court. During the MCO period, victims were unable to obtain court-issued IPOs. Alternative methods to obtain protection orders need to be made in order to safeguard the victim. (Randawar \& Jayabalan, 2014). Many companies, industries, schools and higher learning institutions have embraced and utilized electronic technologies as a way of life during this pandemic. Likewise, the justice system will have to adopt virtual court hearings and exploit online platforms to facilitate protection orders (Lopez, 2020). 


\section{Comparative Perspective}

There are several international examples of proactive approaches in dealing with domestic violence during the lockdown period of COVID-19 which are effective. Taking lessons and suggestions from some countries is paramount. The first is a system that was launched in the Canary Islands by the regional government and pharmacies enabling a woman to communicate through code requesting for "Mask-19." The code indicates that a woman who desperately requires help with a domestic violence situation and the pharmacist upon hearing the request will then immediately contact the police. (Oakley, 2020). Second, the French government recently announced it would house victims of domestic violence in hotel rooms and finance "pop-up" counselling centres in grocery stores due to the increase of domestic violence cases since the lockdown began on March 17 (Godin, 2020).

Third, in Nova Scotia under Section 6 of the Domestic Violence Intervention Act 2001 (DVIA) a victim or any person acting on behalf of a victim with the approval of a Justice of the Peace, or a designated person can apply for an EPO (Family Law Nova Scotia). Moreover, applications for an EPO are done over the phone anywhere in Nova Scotia by calling 1-866816-6555, any day between 9 am and 9 pm without having to complete paperwork. Under Section 8 of the DVIA, an EPO can provide a victim exclusive occupation of the home for up to 30 days, temporary care and custody of a child, and even evict the perpetrator from the home (Family Law Nova Scotia).

Another example is seen in Latin America, in which the COVID-19 pandemic is straining the criminal justice systems with severe restrictions on movement and social distancing, thus imposing enormous challenges to the operation of courts (Santiago, 2020). One response by some Latin American countries, including Bolivia, Ecuador, and Argentina, has been to introduce virtual court hearings for pre-trial detainees, and other governments in the region are considering to adopt similar measures (Santiago, 2020).

Likewise, The Eleventh Judicial Circuit of Florida has initiated Domestic Violence Bond and Emergency Hearings to be held on Zoom Virtual Court Platform. As such judges from the Domestic Violence Division will be assigned to cover each week's bond hearings and emergency motions on a rotational basis (The Eleventh Judicial Circuit, 2020). Hearing protocols are also made available for the parties (The Eleventh Judicial Circuit, 2020).

Furthermore, in Malta, the Ministry for Justice, Equality and Governance has declared that despite their closure, the courts have the power to hear urgent cases or any cases of public interest including cases of domestic violence (Council of Europe).

In Georgia under Article 19, a toll-free support line, 24-hour emergency service is available in order to provide assistance and advice on relevant issues to persons affected by domestic violence. This 24-hour emergency service line will be provided throughout the country.

A measure taken by the Scottish Government should be applauded wherein a national campaign was re-launched to reassure anyone experiencing domestic abuse that support is available round the clock for them during these difficult times (9 April, 2020). According to Justice Secretary Humza Yousaf, while victims may feel secluded and alone, and express their intention not to bother the police or support services because of the crisis, services remain open, to assist them (9 April, 2020). Victims of domestic violence have been found to lack selfconfidence and have poor self-esteem due the abuse and sufferings they have to endure. However, support from the authorities will help these victims to become stronger and to break free from the clutches of domestic violence. 


\section{Conclusion and Recommendations}

Despite the current restrictions imposed on daily life as a result of the COVID-19 outbreak, help is available for anyone who is, or is likely to become, a victim of domestic violence. Prior to the global lockdown, the Malaysian government has taken necessary measures to combat gender-based violence. Though we understand the government's predicament, viable measures are required to guarantee the safety of victims in homes plagued by violence. Hence, every party has to collaborate in providing support to victims of domestic violence.

Reaching out to women in times of need is crucial for the well-being of the woman and her family. During these trying times, government and non-governmental bodies should collaborate to set up temporary shelters to house victims of domestic violence. The government can also collaborate with the private sector in providing shelter. It is important to move the victims to safer places and as such, initiative can be taken, if necessary, by converting empty hotels and universities campus building into temporary shelters in urban areas. Through the mosque project as a Transit Center and Shelter for Victims of Domestic Violence, the Ministry of Women, Family and Community Development Malaysia through its agency Department of Women Development (JPW) in collaboration with the Federal Territory Islamic Religious Department has made 14 selected mosques in WP Kuala Lumpur, Mosques as Transit Centers and Shelters for Victims of Domestic Violence (JPW, 2021). The mosque will receive and provide shelter to the victims of the household by providing temporary shelter, food and drink, advice and counseling services as well as provided a Dressing Kit by the Mosque and is also open to Muslims and non-Muslims (JPW, 2021).

Virtual online hearing is essential so that victims can make online applications for necessary protection orders. The COVID-19 outbreak has forced every industry and organization to exploit digital platforms. In order to practice social distancing, a "contactless" trial, for example, was conducted by the people's court of Hainan District in northern China's Inner Mongolia Autonomous Region through a video call with separate computer screens presenting images of the judge, public prosecutor and defendant (Huaxia, 2020). Proceedings being conducted remotely will ensure that cases are heard without unnecessary delay and justice can be served to injured parties.

The COVID-19 pandemic has shaken the world's economy plunging many countries into a recession (Ozili \& Arun, 2020). As a result of the outbreak, certain policy decisions made by many governments have had positive and negative effects on their respective economy. With almost the entire global economy at a standstill in order to contain the spread of the novel coronavirus, job losses are expected to be significant $(\mathrm{Ng}, 2020)$. Unemployment and major financial setbacks faced by many may intensify domestic problems at homes. Financial dependence on a spouse is one of the obstacles for a victim of domestic violence seeking to escape the abuse. Thus, financial support is essential for these victims to enable them to leave and restart their life.

The government should, therefore, provide toll-free numbers for victims to call and report cases and these calls must be resourced with adequate staff and made easily accessible. In Malaysia necessary step has been taken to curb domestic violence with support and help from government and non-governmental organization such as Women Aid Organisation (WAO), AWAM and Sisters in Islam (SIS) (Jayamanogaran,2020). Those requiring help may contact the Women's Aid Organisation's 24-hour hotline at 03-7956 3488 or WhatsApp Tina at 018-988 8058; the Women's Centre for Change, Penang at 011$31084001,016-4287265,016-4180342$ or 016-439 0698, Sisters in Islam's hotline (call or 
WhatsApp) 011- 23701006 (8am -10pm), Awam at 016-237 4221 or Talian Kasih at 15999 which has been set up by the Women, Family and Community Development Ministry (Indramalar,2020). Support and help from friends, family, neighbours and community members can be a vital lifeline to those living with domestic violence. Help can be extended in many ways: by offering practical support, by accompanying the victim to seek help from organisations and the police, and by providing temporary shelter and childcare facilities.

The Government should make some exceptions to the Movement Restriction Order in order to allow the reporting of domestic violence specifically in times of urgency like the COVID-19. The introduction of the EPO under the DVA 1994 has seen to be a good move to provide a cooling period to both victim and abuser as it provides orders prohibiting the abuser from entering the residence of the victim. Its feasibility of being issued within two hours after the application is made shows the urgency of the issues. The application of an EPO can be made by calling Talian Kasih (15999) which is available 24 hours. The suggested recommendations and benefits are condensed in Table 1 below:

Table 1: Suggested Recommendations and Benefits

\begin{tabular}{|c|c|}
\hline SUGGESTED RECOMMENDATIONS & BENEFITS \\
\hline Setting up temporary shelters & Victims can be moved to safer places \\
\hline Providing virtual online hearing & $\begin{array}{l}\text { Victims receive necessary protection orders } \\
\text { during lockdowns }\end{array}$ \\
\hline Providing financial support & $\begin{array}{l}\text { Victims who suffer loss of jobs gain financial } \\
\text { assistance }\end{array}$ \\
\hline $\begin{array}{l}\text { Setting up toll-free numbers with adequate } \\
\text { staff and which are easily accessible }\end{array}$ & $\begin{array}{l}\text { Victims get immediate help and } \\
\text { constructive advice }\end{array}$ \\
\hline $\begin{array}{l}\text { Making exceptions to movement restriction } \\
\text { during a lockdown }\end{array}$ & $\begin{array}{l}\text { Victims can seek help and protection in } \\
\text { times of urgency }\end{array}$ \\
\hline
\end{tabular}

The COVID-19 crisis has transited the society to a digitilized platform. Due to mobility restrictions this shift was essentially required to ease the barriers faced by the society. Businesses, schools, health works and manufactures, with the introduction of necessary apps, have accepted this transmission to ensure comfort and safety practices to maintain critical support for the community. The COVID-19 pandemic has indeed undeniably taken a toll on the world. Even, before the global lockdown, Malaysia government have taken necessary steps to combat gender-based violence. Though we understand the government predicament, yet necessary measures need to be taken to ensure the safety of the victims in a domestic violence home.

\section{Acknowledgement}

This work was supported by the Faculty of Law, Universiti Teknologi Mara (UiTM), 40450 Shah Alam, Selangor Darul Ehsan, Malaysia.

\section{References}

Baharin, M. F. (2020). MCO Sees Spike in Domestic Violence Cases. https://web16.bernama.com/en/general/news_coronavirus.php?id=1843405

Campbell, A. M. (2020) An Increasing Risk of Family Violence during the Covid-19 Pandemic: Strengthening Community Collaborations to save lives. Forensic Science International: Reports. Doi: 10.1016/j.fsir.2020.100089 
Godin, M. (2020). French Government to House Domestic Abuse Victims in Hotels as Cases Rise During Coronavirus Lockdown. Time.

https://time.com/5812990/france-domestic-violence-hotel-coronavirus/

Huaxia. (2020). China Focus: China moves courts online amid coronavirus epidemic Xin Hua Net.

http://www.xinhuanet.com/english/2020-02/18/c_138795315.htm

Indramalar, S. (2020). Emergency measures needed to help victims of violence be safe. The Star. https://www.thestar.com.my/lifestyle/family/2020/04/18/emergency-measuresneeded-to-help-victims-of-violence-be-safe

Jabatan Pembangunan Wanita (JPW). (2021). Mosque as a Transit Center and Shelter for Victims of Domestic Violence. https://tinyurl.com/fw2ywzk

Jayamanogaran, T. (2020). Covid-19: With 'stay-at-home' order enforced, domestic violence back on the rise in Malaysia, The Star.

https://www.malaymail.com/news/malaysia/2020/04/03/covid-19-with-stay-athome-order-enforced-domestic-violence-back-on-the-ris/1853003

Kapoor, A. (2020) Fighting the Menace of Domestic Violence During Pandemic, Qrius. https://qrius.com/fighting-the-menace-of-domestic-violence-during-pandemic/

Lopez, C. B. (2020), A Double Pandemic: Domestic Violence in the Age of COVID-19 https://www.cfr.org/in-brief/double-pandemic-domestic-violence-age-covid-19

Makhbul, Z. K. M. (2020). Challenges on accepting change post-Covid-19, New Straits Times.https://www.nst.com.my/opinion/columnists/2020/05/589561/challengesaccepting-change-post-covid-19

$\mathrm{Ng}$, J. (2020) Special Report: Covid-19 fallout: Jobs under threat. The Edge Markets. https://www.theedgemarkets.com/article/special-report-covid19-fallout-jobs-underthreat

Ozili, P. K., \& Arun, T. G. (2020) Spillover of COVID-19: Impact on the Global Economy, SSRN Electronic Journal. DOI: 10.2139/ssrn.3562570

Oakley, J. (2020). Gender Violence Initiative "Mascarilla-19" Helps Three Women Across Andulcia Since Launch, The Olive Press.

https://www.theolivepress.es/spain-news/2020/04/08/gender-violence-initiativemascarilla-19-helps-three-women-across-andulcia-since-launch/

Ramaswamy, M., Hemberg, J., Faust, A., Wickliffe, J., Comfort, M., Lorvick, J., \& Cropsey, K. (2020). Criminal Justice-Involved Women Navigate COVID-19: Notes from the Field. Health Education \& Behavior. https://doi.org/10.1177/1090198120927304

Randawar, D. K. (2016). Have Child Custody and Right of Access been Overlooked under the Domestic Violence Act 1994 in Malaysia? Mediterranean Journal of Social Sciences MCSER. Vol.7 No. 5, 11-17.

Randawar, D. K., \& Jayabalan, S. (2018). The Definition of Domestic Violence in Malaysia: A Cross-National Comparison. Akademika, Journal of Southeast Asia Social Sciences and Humanities 88(3), 77-89

Randawar, D. K., \& Zin, N. M. (2019) The Law on Domestic Violence in Malaysia. Gombak: IIUM Press. p. 100.

Randawar, D. K., \& Jayabalan, S. (2014) Wife Battering-A Malaysian Perspective, Proceedings of the Colloquium on Administrative Science and Technology, 275-283 (ISBN: 978-9814585-44-6, DOI: 10.1007/978-981-4585-45-3_28

Rashid, H. N. (2020). COVID-19 crisis: Crime, poverty and the need to evolve social security, Astro Awani. 
http://english.astroawani.com/malaysia-news/covid-19-crisis-crime-poverty-andneed-evolve-social-security-237089

Santiago, B. J. (2020). COVID-19 Conversations: Virtual court hearings in Latin America. https://www.equalitynow.org/covid_19_lac_virtual_court_hearings

Scottish Government. (2020) Supporting domestic abuse victims. https://www.gov.scot/news/supporting-domestic-abuse-victims/

Sukumaran, T. (2020). In Malaysia, domestic violence spikes amid lockdown to slow coronavirus infections, South China Morning Post.

https://www.scmp.com/week-asia/people/article/3079456/malaysia-domesticviolence-spikes-amid-lockdown-slow-coronavirus

The Eleventh Judicial Circuit. (2020). Domestic Violence Bond and Emergency Hearings to be Held on Zoom Virtual Court Platform Starting. https://www.jud11.flcourts.org/coronavirus/ArtMID/2392/ArticlelD/3459/DomesticViolence-Bond-and-Emergency-Hearings-to-be-Held-on-Zoom-Virtual-Court-PlatformStarting-April-22-2020

Timbuong, J. (2020). Man who hurt wife and father-in-law found dead in Bangi home. The Star.https://www.thestar.com.my/news/nation/2020/04/30/man-who-hurt-wifeand-father-in-law-found-dead-in-bangi-home

Wu, Y. C., Yi, C. C., Chan, Y. J. (2020) The outbreak of COVID-19: An overview, Journal of the Chinese Medical Association, 83(3), 217-220.

Doi10.1097/JCMA.0000000000000270 